\title{
Resting Potential and Submembrane Calcium Concentration of Inner Hair Cells in the Isolated Mouse Cochlea Are Set by KCNQ-Type Potassium Channels
}

\author{
Dominik Oliver, ${ }^{1}$ Marlies Knipper, ${ }^{2}$ Christian Derst, ${ }^{1}$ and Bernd Fakler ${ }^{1}$ \\ ${ }^{1}$ Physiologisches Institut der Universität Freiburg, 79104 Freiburg, Germany, and ${ }^{2}$ Tübingen Hearing Research Centre, Molecular Neurobiology, 72076 \\ Tübingen, Germany
}

Cochlear inner hair cells (IHCs) transduce sound-induced vibrations into a receptor potential (RP) that controls afferent synaptic activity and, consequently, frequency and timing of action potentials in the postsynaptic auditory neurons. The RP is thought to be shaped by the two voltage-dependent $\mathrm{K}^{+}$conductances, $I_{\mathrm{K}, \mathrm{f}}$ and $I_{\mathrm{K}, \mathrm{s}}$, that are carried by large-conductance $\mathrm{Ca}^{2+}$ - and voltage-dependent $\mathrm{K}^{+}(\mathrm{BK})$ - and $\mathrm{K}_{\mathrm{V}}$-type $\mathrm{K}^{+}$channels. Using whole-cell voltage-clamp recordings in the acutely isolated mouse cochlea, we show that IHCs display an additional $\mathrm{K}^{+}$current that is active at the resting membrane potential $(-72 \mathrm{mV})$ and deactivates on hyperpolarization. It is potently blocked by the KCNQ-channel blockers linopirdine and XE991 but is insensitive to tetraethylammonium and 4-aminopyridine, which inhibit $I_{\mathrm{K}, \mathrm{f}}$ and $I_{\mathrm{K}, \mathrm{s}}$, respectively. Single-cell PCR and immunocytochemistry showed expression of the KCNQ4 subunit in IHCs. In current-clamp experiments, block of the KCNQ current shifted the resting membrane potential by $\sim 7$ to $-65 \mathrm{mV}$ and led to a significant activation of BK channels. Using BK channels as an indicator for submembrane intracellular $\mathrm{Ca}^{2+}$ concentration $\left(\left[\mathrm{Ca}^{2+}\right]_{\mathrm{i}}\right)$, it is shown that the shift in IHC resting potential observed after block of the KCNQ channels leads to an increase in $\left[\mathrm{Ca}^{2+}\right]_{\mathrm{i}}$ to values $\geq 1 \mu \mathrm{M}$. In conclusion, KCNQ channels set the resting membrane potential of IHCs in the isolated organ of Corti and thus maintain $\left[\mathrm{Ca}^{2+}\right]_{\mathrm{i}}$ at low levels. Destabilization of the resting potential and increase in $\left[\mathrm{Ca}^{2+}\right]_{i}$, as may result from impaired KCNQ4 function in IHCs, provide a novel explanation for the progressive hearing loss (DFNA2) observed in patients with defective KCNQ4 genes.

Key words: $\mathrm{KCNQ}$ channels; intracellular $\mathrm{Ca}^{2+}$; BK channels; progressive hearing loss; hereditary deafness (DFNA2); cochlea

\section{Introduction}

The physiological functions of $\mathrm{K}^{+}$channels in the inner ear include setting of the resting potential and shaping the voltage responses of sensory hair cells and neurons (Housley and Ashmore, 1992; Santos-Sacchi, 1993; Kros et al., 1998), synaptic inhibition in hair cells (Fuchs and Murrow, 1992; Oliver et al., 2000), generation of the endocochlear potential, and establishment of the high $\mathrm{K}^{+}$concentration of the endolymph (Wangemann, 2002).

Recently, mutations in the KCNQ4 $\mathrm{K}^{+}$channel gene have been shown to underlie the progressive autosomal dominant hearing loss classified as DFNA2 (Kubisch et al., 1999). The pathophysiological mechanisms behind this deafness are not well understood. KCNQ4 is expressed strongly in the basolateral membrane of cochlear outer hair cells (OHCs) and is thought to constitute the major $\mathrm{OHC} \mathrm{K}{ }^{+}$conductance $I_{\mathrm{K}, \mathrm{n}}$ (Housley and Ashmore, 1992; Marcotti and Kros, 1999; Kharkovets et al., $2000) . I_{\mathrm{K}, \mathrm{n}}$ provides a large $\mathrm{K}^{+}$conductance at the resting potential of the cell and thus determines the membrane potential and membrane time constant (Housley and Ashmore, 1992; Marcotti and Kros, 1999). Current models suggest that loss of this conduc-

\footnotetext{
Received 0ct. 21, 2002; revised Dec. 17, 2002; accepted Dec. 19, 2002.

This work was supported by grants from the Deutsche Forschungsgemeinschaft to B.F. (Sonderforschungsbereich 430, A1) and to M.K. (Sonderforschungsbereich 430, B3). We thank Dr. T. Jentsch for the gift of the KCNQ4 antibody and for reading this manuscript, Dr. A. Mack for support with confocal microscopy, Drs. J. Engel and T. Moser for reading this manuscript, and members of the Physiology Department in Freiburg for stimulating discussions.

Correspondence should be addressed to Dr. Dominik Oliver, Physiologisches Institut, Universität Freiburg, Hermann-Herder-Strasse 7, 79104 Freiburg, Germany. E-mail: dominik.oliver@physiologie.uni-freiburg.de. Copyright $\odot 2003$ Society for Neuroscience $\quad 0270-6474 / 03 / 232141-09 \$ 15.00 / 0$
}

tance in KCNQ4/DFNA2 patients will impair $\mathrm{K}^{+}$efflux from OHCs, which should lead to a $\mathrm{K}^{+}$overload and finally result in degeneration of OHCs (Jentsch, 2000; Kharkovets et al., 2000).

There is, however, an intrinsic problem with this model arising from the function of OHCs: although OHCs provide active amplification of sound-induced vibrations, they do not convey afferent sensory information (for review, see Dallos, 1992). Accordingly, the loss of $\mathrm{OHCs}$ or $\mathrm{OHC}$ function is known to result in an increased hearing threshold of at most 40-50 dB (Ryan and Dallos, 1975) but not in the severe hearing loss observed in DFNA2 patients (Marres et al., 1997; De Leenheer et al., 2002).

Alternatively, hearing loss in DFNA2 may result from a defective afferent signal transmission, from either a defective central auditory pathway whose neurons are known to express KCNQ4 (Kharkovets et al., 2000) or functional defects in inner hair cells (IHCs) (Takeno et al., 1994; Wang et al., 1997). Information on expression of KCNQ4 in IHCs, however, has been contradictory. Although initially no detectable expression in IHCs was reported (Kubisch et al., 1999), more recent articles suggest at least some expression in IHCs (Beisel et al., 2000; Kharkovets et al., 2000). Electrophysiologically, two $\mathrm{K}^{+}$current components have been characterized $\left(I_{\mathrm{K}, \mathrm{f}}\right.$ and $\left.I_{\mathrm{K}, \mathrm{s}}\right)$, both of which are outwardly rectifying (Kros and Crawford, 1990). $I_{\mathrm{K}, \mathrm{f}}$ is carried by largeconductance $\mathrm{Ca}^{2+}$ - and voltage-dependent $\mathrm{K}^{+}(\mathrm{BK})$ channels, as shown by its submillisecond kinetics and block by tetraethylammonium (TEA), charybdotoxin, and iberiotoxin (Kros et al., 1998). $I_{\mathrm{K}, \mathrm{s}}$ is probably carried by $\mathrm{K}_{\mathrm{V}}$-type channels, as concluded from its slower kinetics and sensitivity to 4-aminopyridine (4- 
AP). It has been suggested that these currents shape the voltage response and the resting potential of IHCs (Kros et al., 1998).

Here, we investigate the presence of KCNQ currents in IHCs. We find a novel current with high sensitivity to KCNQ-channel blockers. Moreover, KCNQ4 expression in IHCs could be verified by immunofluorescence and single-cell reverse transcription (RT)-PCR, raising the possibility that IHC dysfunction might contribute to hearing loss in DFNA2.

\section{Materials and Methods}

Electrophysiology. Apical cochlear turns of mice (NMRI; 22-32 d after birth; Charles River Laboratories, Sulzfeld, Germany) and rats (Wistar; 26-28 d after birth; Charles River Laboratories) were isolated as described previously (Oliver et al., 2000). Briefly, animals were killed by decapitation, cochleae were dissected, and the organ of Corti was separated from the modiolus and stria vascularis. The apical turn of the organ of Corti was placed in an experimental chamber continuously perfused with standard extracellular solution containing the following (in $\mathrm{mM}$ ): $144 \mathrm{NaCl}, 5.8 \mathrm{KCl}, 1.3 \mathrm{CaCl}_{2}, 0.9 \mathrm{MgCl}_{2}, 10$ HEPES, $0.7 \mathrm{Na}_{2} \mathrm{HPO}_{4}$, and 5.6 glucose, with $\mathrm{pH}$ adjusted to 7.3 with $\mathrm{NaOH}$. Access to the IHC basolateral membrane was gained by removal of supporting cells surrounding the IHC with a suction pipette.

Whole-cell and inside-out patch-clamp recordings were done with an Axopatch 200B amplifier (Axon Instruments, Foster City, CA) at room temperature $\left(22-24^{\circ} \mathrm{C}\right)$. Electrodes were pulled from quartz glass and had initial resistances of $1.5-2.5 \mathrm{M} \Omega$.

For whole-cell measurements, pipettes were filled with intracellular solution containing the following (in $\mathrm{mm}$ ): $135 \mathrm{KCl}, 3.5 \mathrm{MgCl}_{2}, 0.1$ $\mathrm{CaCl}_{2}, 5$ EGTA, 5 HEPES, and $2.5 \mathrm{Na}_{2} \mathrm{ATP}$, with $\mathrm{pH}$ adjusted to 7.3 with $\mathrm{KOH}$. In one set of experiments, $10 \mathrm{~mm} 4-\mathrm{AP}-\mathrm{Cl}$ was added to the pipette solution to block $I_{\mathrm{K}, \mathrm{s}}$ currents. Residual whole-cell series resistance $\left(R_{\mathrm{s}}\right)$ after application of series resistance compensation $(70-95 \%)$ was $<1$ $\mathrm{M} \Omega$. Membrane voltage was not corrected for errors $(<3 \mathrm{mV})$ resulting from residual $R_{\mathrm{s}}$; residual $R_{\mathrm{s}}$ is given in the figure legends where necessary. Voltage-clamp recordings were low-pass filtered at $2 \mathrm{kHz}$ (for KCNQ currents) or $10 \mathrm{kHz}$ (for BK currents), and sampling rate was 10 or $50 \mathrm{kHz}$, respectively. Membrane potential was measured under current clamp using the zero-current mode of the amplifier, and recordings were low-pass filtered at $1 \mathrm{kHz}$ and sampled at $5 \mathrm{kHz}$. TEA, linopirdine (lot LEL497A; Research Biochemicals, Natick, MA), and XE991 (DuPont NEN, Wilmington, DE) were added to the extracellular medium from stock solutions and applied via a glass capillary positioned close to the organ of Corti. Stock solutions of linopirdine and XE991 were prepared in dimethylsulfoxide (final concentration, $\leq 0.1 \%$ ). External solutions with different $\left[\mathrm{K}^{+}\right]$were prepared by substituting $\mathrm{KCl}$ for an equal amount of $\mathrm{NaCl}$.

For inside-out recordings, patch pipettes were filled with standard extracellular solution. After excision, patches were placed in front of an array of capillaries that allowed exchange between solutions with different free $\left[\mathrm{Ca}^{2+}\right]$. Composition of these solutions was as follows (in $\mathrm{mm}$ ): $135 \mathrm{KCl}, 1 \mathrm{MgCl}_{2}, 5 \mathrm{HEPES}$, and $104-\mathrm{AP}-\mathrm{Cl}$, with $\mathrm{pH}$ adjusted to 7.3 with $\mathrm{HCl}$. Free $\left[\mathrm{Ca}^{2+}\right]$ was buffered with $2 \mathrm{~mm}$ dibromo-BAPTA $\left[K_{\mathrm{D}}(\mathrm{Ca}), 1.8 \mu \mathrm{M}\right.$ at $23^{\circ} \mathrm{C}$; $\mathrm{pH}$ 7.3; Fluka, Seelze, Germany] to 1,3 , and $10 \mu \mathrm{M}$ by adding $0.705,1.240$, and $1.690 \mathrm{mM} \mathrm{CaCl}_{2}$, respectively. For $\left[\mathrm{Ca}^{2+}\right]=0$, the solution contained $5 \mathrm{~mm} \mathrm{~K} \mathrm{~K}_{2}$ EGTA instead of dibromoBAPTA. Free $\left[\mathrm{Ca}^{2+}\right]$ was verified using a $\mathrm{Ca}^{2+}$-sensitive electrode (World Precision Instruments, Berlin, Germany).

Activation curves of membrane currents were obtained by using the tail current protocols indicated in Results. For conductance-voltage $(G-V)$ plots, tail current amplitudes were plotted as a function of the prepulse potential for each cell or patch and were fitted with a first-order Boltzmann function: $I=I_{\text {leak }}+I_{\max } /\left(1+\exp \left(-\left(V-V_{\mathrm{h}}\right) / \alpha\right)\right)$, where $I_{\text {leak }}$ is voltage-independent leak current, $I_{\max }$ is the amplitude of the fully activated current at the tail current voltage, $V$ is prepulse voltage, $V_{\mathrm{h}}$ is voltage at half-maximal activation, and $\alpha$ is slope factor. $I_{\text {leak }}$ was subtracted, and currents were normalized to $I_{\max }$ to yield $G_{\text {norm }}$ for each experiment. The $G-V$ curves shown are averaged data from $n$ experiments. The slope conductance provided by the KCNQ-type current in
IHCs was derived from the instantaneous current measured at potentials between -84 and $-64 \mathrm{mV}$.

All voltages were corrected for measured liquid junction potentials (4.0 and $3.7 \mathrm{mV}$ for whole-cell and inside-out recordings, respectively). Data analysis and fitting was performed with IgorPro (WaveMetrics, Lake Oswego, OR) on a Macintosh PowerPC (Apple Computers, Cupertino, CA). All data are presented as mean $\pm \mathrm{SD}$.

Immunocytochemistry and laser confocal microscopy. Cochleae of mice and rats (between 2 weeks and 3 months old) were isolated, dissected, and fixed as described previously (Knipper et al., 2000). Cochleae were decalcified after fixation for $1 \mathrm{~min}$ to $1 \mathrm{hr}$ in Rapid Bone Decalcifier (Eurobio, Fisher Scientific, Nidderau, Germany). After overnight incubation, cochleae were embedded in O.C.T. compound (Miles Laboratories, Elkhart, IN). Cochlear sections $(10 \mu \mathrm{M})$ were thawed, permeabilized with $0.1 \%$ Triton X-100 in PBS for 3 min at room temperature, preblocked with $1 \%$ bovine serum albumin in PBS, and incubated overnight at $4^{\circ} \mathrm{C}$ with two different primary anti-KCNQ 4 antibodies [one described by Kharkovets et al. (2000) and kindly provided by T. Jentsch (Zentrum für Molekulare Neurobiologie, Hamburg, Germany); the other, affinitypurified goat anti-KCNQ4 antibody, from Santa Cruz Biotechnology (Santa Cruz, CA)] at a dilution of 1:50; the specificity of the staining was tested by preincubation of the goat anti-KCNQ 4 antibody with the antigenic peptide (sc-9385) as described by the manufacturer. In addition, in some experiments, affinity-purified sheep anti-synaptophysin was used at a dilution of 1:2500. For revealing immunoreactivity of KCNQ4, either an anti-rabbit Cy3-conjugated antibody $(0.35 \mu \mathrm{g} / \mathrm{ml}$ for $60 \mathrm{~min}$; Jackson ImmunoResearch, West Grove, PA) or an anti-goat Alexa-Fluor-488conjugated antibody (1:1500; Molecular Probes, MoBiTec, Göttingen, Germany) was used as a secondary IgG antibody. For detecting immunoreactivity of synaptophysin, anti-sheep Alexa Fluor 555 (1:6000; Molecular Probes, MoBiTec) was used as a secondary IgG antibody. For additional nuclear staining, sections were embedded with Vectashield mounting medium with 4',6'-diamidino-2-phenylindole (DAPI) (Vector Laboratories, Burlingame, CA).

Sections were imaged either with an Olympus Optical (Tokyo, Japan) AX70 microscope equipped with epifluorescence illumination or with a confocal laser scanning microscope (LSM 410) mounted on an Axiovert $135 \mathrm{M}$ (Zeiss, Oberkochen, Germany). Stacks of confocal images with a step interval of $0.4 \mu \mathrm{m}$ were taken over a total $z$-distance of $11.2 \mu \mathrm{m}$ and reconstructed on a Silicon Graphics (Mountain View, CA) computer with Voxel View software.

Single-cell multiplex RT-PCR. Organs of Corti from mice (apical turn, 22-25 d after birth) were prepared as described for electrophysiology. Cytoplasm of IHCs, OHCs, and Deiters' cells was harvested with a patchclamp capillary that contained $1 \mu \mathrm{l}$ of intracellular buffer (in mM: 160 $\mathrm{KCl}, 3 \mathrm{MgCl}_{2}$, and $1 \mathrm{HEPES}$ ) and was sealed onto the plasma membrane. After rupture of the membrane, the cell content was collected by gentle suction under visual control and expelled directly into the RT reaction (total reaction volume of $10 \mu \mathrm{l}$ ). For controls, fluid surrounding the cells was collected. RT was performed with a mixture of $5 \mu \mathrm{M}$ random hexanucleotides (Roche Molecular Biochemicals, Mannheim, Germany) and 50 pmol of the outer reverse PCR primers (see below), $10 \mathrm{~mm}$ dithiothreitol, $1 \mathrm{~mm}$ dNTPs (Fermentas, St. Leon-Rot, Germany), $10 \mathrm{U}$ of RNasin RNase inhibitor (Promega, Mannheim, Germany), and $100 \mathrm{U}$ of Superscript II reverse transcriptase (Invitrogen, Karlsruhe, Germany) at $42^{\circ} \mathrm{C}$ overnight. A nested multiplex-PCR approach was used to amplify KCNQ4 and glyceraldehyde-3-phosphate dehydrogenase (GAPDH). The primers were the following: rat KCNQ4 outer primers (deduced from GenBank accession number AC129237.2), 5' -GCCAAGCAGTGAGCAGGT-3' (sense), 5'-GATGACCGTCTTCACAGCAG-3' (reverse); rat KCNQ4 inner primers, 5'-CCCAGCAAGGTGCAGAAAAG-3' (sense), 5'-CATCATCCACCGTAAGCTCACA-3' (reverse); rat GAPDH outer primers, 5'-TCGTCTCATAGACAAGATGGTGA-3' (sense), 5' -TTCCCATTCTCAGCCTTGAC-3' (reverse); and rat GAPDH inner primers, 5'-TCGGTGTCAACGGATTTGG-3' (sense), 5'-AACTTGCCGTGGGTAGAATCA-3' (reverse). The first multiplex-PCR reaction (GAPDH and KCNQ4) comprised 40 cycles $\left(94^{\circ} \mathrm{C}\right.$ for $30 \mathrm{sec}, 52^{\circ} \mathrm{C}$ for $30 \mathrm{sec}$, and $72^{\circ} \mathrm{C}$ for $40 \mathrm{sec}$ ) and was done in a total reaction volume of $50 \mu \mathrm{l}$ using AmpliTaq Gold DNA-polymerase (Applied Biosystems, Weiterstadt, Germany) and 50 
pmol of outer primers. The nested PCR reactions comprised 40 cycles $\left(94^{\circ} \mathrm{C}\right.$ for $30 \mathrm{sec}, 55^{\circ} \mathrm{C}$ for $30 \mathrm{sec}$, and $72^{\circ} \mathrm{C}$ for $30 \mathrm{sec}$ ) and were performed separately for KCNQ4 and GAPDH using $1 \mu \mathrm{l}$ of the first reaction as starting material and $10 \mathrm{pmol}$ of the inner primers. All primers were designed with the program PrimerExpress (Applied Biosystems), and the final nested PCR products ( $150 \mathrm{bp}$ each) were visualized on $2 \%$ agarose gels. KCNQ4 amplification was verified by direct sequencing of the PCR products.

\section{Results}

\section{Resting potential in cochlear IHCs is set by KCNQ-type} $\mathrm{K}^{+}$channels

When investigated by current-clamp whole-cell recordings, mouse IHCs exhibited stable resting membrane potentials $\left(V_{\mathrm{R}}\right)$ of $-72.4 \pm 1.2 \mathrm{mV}(n=11)$. As shown in Figure $1 A$, this $V_{\mathrm{R}}$ did not change when $5 \mathrm{~mm}$ TEA, which effectively suppressed the fast BK-mediated $\mathrm{IHC} \mathrm{K}^{+}$conductance $I_{\mathrm{K}, \mathrm{f}}($ Fig. $1 B)$, was applied to the extracellular surface of IHCs $\left(\Delta V_{\mathrm{R}}=+0.5 \pm 0.2 \mathrm{mV} ; n=\right.$ 11). In contrast, a considerable shift in $V_{\mathrm{R}}$ of $+6.9 \pm 1.2 \mathrm{mV}$ (to $-64.7 \pm 2.1 \mathrm{mV} ; n=7)$ was observed after application of linopirdine $(10 \mu \mathrm{M})$, a selective blocker of KCNQ-type $\mathrm{K}^{+}$channels (Wang et al., 1998). This indicated that, whereas $I_{\mathrm{K}, \mathrm{f}}$ contributes little to $V_{\mathrm{R}}$, a distinct, linopirdine-sensitive conductance sets the resting membrane potential of IHCs in the isolated organ of Corti.

Different from the application under resting conditions, reapplication of TEA in the presence of linopirdine caused a shift in $V_{\mathrm{R}}$ by $2.7 \pm 0.7 \mathrm{mV}$ (to $-61.3 \pm 2.3 \mathrm{mV} ; n=4$ ) (Fig. $1 A$ ), suggesting that a significant fraction of $I_{\mathrm{K}, \mathrm{f}}$ was activated and thus contributed to $V_{\mathrm{R}}$, presumably together with the delayed rectifier $I_{\mathrm{K}, \mathrm{s}}$ (Kros and Crawford, 1990).

\section{Identification and characterization of the KCNQ channels in IHCs}

We next attempted to characterize the linopirdine-sensitive conductance active in IHCs at a $V_{\mathrm{R}}$ of approximately $-70 \mathrm{mV}$ under voltage-clamp conditions (Fig. 2). Figure $2 \mathrm{~A}$ shows current traces recorded in response to depolarizing voltage steps from a holding potential of $-84 \mathrm{mV}$. In addition to the well known fast and slowly activating $I_{\mathrm{K}, \mathrm{f}}$ and $I_{\mathrm{K}, \mathrm{s}}$ currents, another current lighted up at the holding potential, well below the activation range of both $I_{\mathrm{K}, \mathrm{f}}$ and $I_{\mathrm{K}, \mathrm{s}}$ (Kros and Crawford, 1990). When investigated in the presence of $5 \mathrm{~mm}$ TEA to suppress the BK-mediated $I_{\mathrm{K}, \mathrm{f}}$, the novel current showed biophysical hallmarks that were very reminiscent of the linopirdine-sensitive KCNQ current, $I_{\mathrm{K}, \mathrm{n}}$, characteristic for cochlear OHCs (Housley and Ashmore, 1992; Marcotti and Kros, 1999).

Thus, the current behaved ohmically at potentials positive to $-70 \mathrm{mV}$ and deactivated on hyperpolarization. The deactivation time course was approximately monoexponential, with time constants ranging from $9.7 \pm 1.3 \mathrm{msec}$ at $-154 \mathrm{mV}$ to $62.0 \pm 7.2$ msec at $-94 \mathrm{mV}(n=9$ IHCs) (Fig. $2 B$ ). The steady-state activation curve determined from tail current experiments as in Figure $2 B$ (see also Materials and Methods) was placed at hyperpolarized potentials similar to the KCNQ current in OHCs (Housley and Ashmore, 1992). Thus, fitting the $G-V$ relationship with a Boltzmann function (see Materials and Methods) yielded a voltage for half-maximal activation $\left(V_{\mathrm{h}}\right)$ of $-85.1 \pm 2.5 \mathrm{mV}$ and a slope factor of $10.5 \pm 0.1 \mathrm{mV}(n=6 \mathrm{IHCs})$ (Fig. $2 C)$. The maximal amplitude of the current as obtained from the Boltzmann fits was $-0.31 \pm 0.09 \mathrm{nA}$ at $-120 \mathrm{mV}\left(I_{\max },-120 \mathrm{mV}\right)$, and the slope conductance provided by the current was $5.1 \pm 1.5 \mathrm{nS}$ $(n=8)$ around the $V_{\mathrm{R}}$. Furthermore, the current displayed high selectivity for $\mathrm{K}^{+}$ions, as illustrated by the Nernstian behavior of

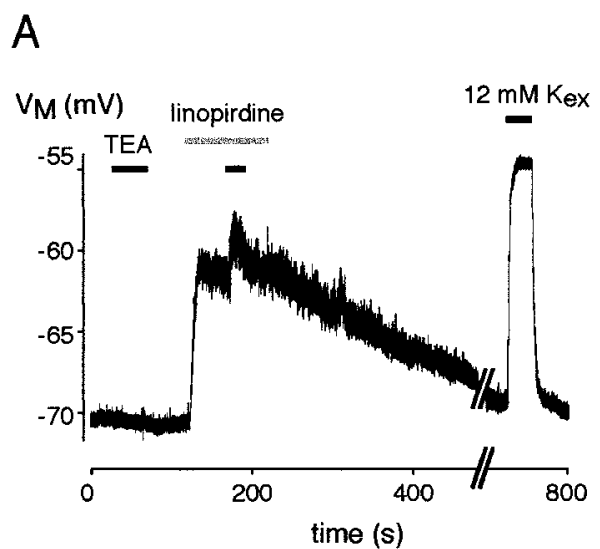

B

Figure 1. Membrane potential of IHCs is set by a conductance sensitive to the KCNQ-channel blocker linopirdine. A, Current-clamp recording (at zero current) from an IHC. Application of the BK blocker TEA (5 mm) had no effect on $V_{R}$. In contrast, $10 \mu \mathrm{m}$ linopirdine depolarized $V_{R}$ in a slowly reversible manner. Note the readily reversible depolarization by TEA in the presence of linopirdine. Application of increased extracellular $\mathrm{K}^{+}$concentration at the end of the experiment is shown to illustrate the speed of solution exchange. $B$, Block of BK-mediated $I_{K, \mathrm{f}}$ currents of an IHC by extracellular TEA ( $5 \mathrm{~mm}$ ). The IHC was voltage clamped at $-84 \mathrm{mV}$ and stepped to voltages between -74 and $16 \mathrm{mV}$ in $10 \mathrm{mV}$ increments [residual $R_{\mathrm{s}}, 0.15 \mathrm{M} \Omega$ (control) and 0.3 $M \Omega(T E A)]$.

the reversal potentials measured at several concentrations of extracellular $\mathrm{K}^{+}$(Fig. 2D).

Similar to the functional properties, the pharmacological profile of the novel IHC current closely matched that of the KCNQtype current of OHCs. It was insensitive to intracellularly applied 4-AP (10 mM; data not shown) and to extracellular TEA (Fig. 2 B). Instantaneous current measured at $-120 \mathrm{mV}$ in the presence of 5 mM TEA was $91 \pm 7 \%$ of the control value $(n=8)$. In contrast to TEA and 4-AP, the current was potently inhibited by the KCNQchannel blockers linopirdine and XE991. As shown in Figure 3, block by linopirdine was dose dependent and slowly reversible. Fitting of a Hill equation to the dose-response curve yielded values for $\mathrm{IC}_{50}$ and the Hill coefficient of $0.58 \mu \mathrm{M}$ and 1.1, respectively. Sensitivity to XE991 was even higher, because $100 \mathrm{~nm}$ blocked $77 \pm 4 \%$ of the current; XE991-induced inhibition appeared to be irreversible, because no recovery was observed throughout the duration of the recordings ( $n=4 \mathrm{IHCs})$. The close agreement in biophysical and pharmacological properties with $I_{\mathrm{K}, \mathrm{n}}$ of OHCs, which is thought to be carried by KCNQ4 channels (Marcotti and Kros, 1999; Kharkovets et al., 2000), suggested that KCNQ4 channels also underlie the linopirdinesensitive current in IHCs.

We therefore probed expression of this channel subunit in mouse IHCs with both immunocytochemistry and single-cell RT-PCR. Immunocytochemistry was done with two different antibodies directed against the $\mathrm{N}$ - and C-terminal domains of KCNQ4 in the cochleae of four mice each. As shown in Figure $4 A-C$, fluorescence microscopy revealed binding of anti-KCNQ4 that could be inhibited with the appropriate blocking peptide in both OHCs and IHCs. Whereas in OHCs, KCNQ4 was localized exclusively into a brightly labeled cap at the basal pole (Kharkovets et al., 2000), staining in IHCs was somewhat weaker and appeared as a spotted pattern predominantly lining the cell membrane (Fig. $4 B$ ). KCNQ4 immunoreactivity was observed in IHCs in all turns of the cochlea from the end of the second postnatal week onward; moreover, an analogous staining pattern of KCNQ4 was observed in the cochleae of all four rats tested (data not shown). The detection of KCNQ4 protein in both IHCs and 
A
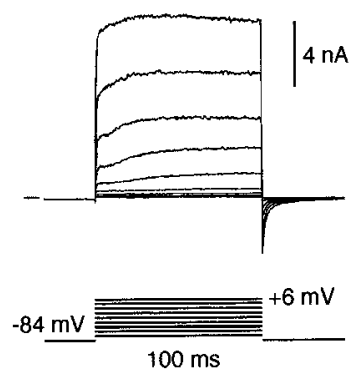

C

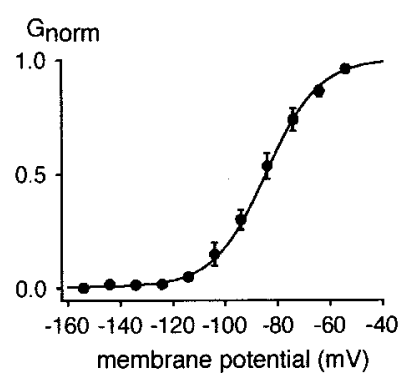

B
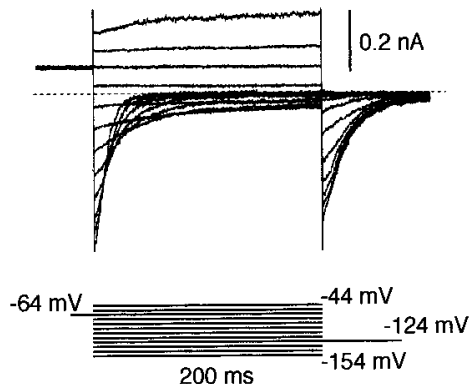

D

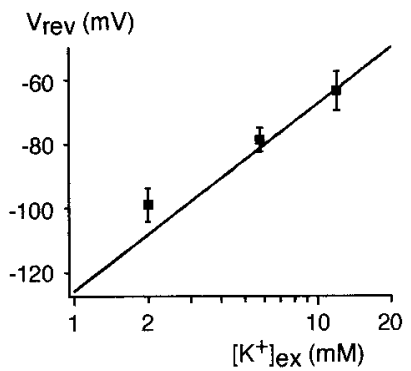

Figure 2. Isolation of a voltage-dependent $\mathrm{K}^{+}$current activated around the $\mathrm{IHC}$ resting potential. $A$, The fast and slow outward current components $I_{\mathrm{K}, \mathrm{f}}$ and $I_{\mathrm{K}, \mathrm{s}}$ (see Introduction) recorded in an $\mathrm{IHC}$ in response to the voltage protocol shown (voltage increment was $10 \mathrm{mV}$; residual $R_{\mathrm{s}}$ was $0.5 \mathrm{M} \Omega$ ). Zero current level is indicated by a horizontal bar. $B$, Current response of the same IHC to the voltage protocol indicated; the experiment was done with $5 \mathrm{~mm}$ TEA present extracellularly to block $I_{\mathrm{K}, \mathrm{f}}$. Note that the recorded current was almost completely activated at the resting potential of approximately $-70 \mathrm{mV}$ and deactivated on hyperpolarization. Activation of $I_{\mathrm{K}, \mathrm{s}}$ occurred only at voltages positive to $-50 \mathrm{mV}$, as apparent in the top trace. Traces are shown with leak current $(65 \mathrm{pA}$ at $-120 \mathrm{mV})$ subtracted. Zero-current level is indicated by the dotted line. C, Activation curve of the novel current recorded in B. Tail current amplitude was taken $1.5 \mathrm{msec}$ after stepping to $-124 \mathrm{mV}$, and prepulse duration at the various potentials was 500 msec to ensure steady-state conditions. Continuous line represents fit of a Boltzmann function (see Materials and Methods) to the normalized currents averaged from six $\mathrm{IHCs}$; values for $V_{\mathrm{h}}$ and slope as yielded by the fit were -84.3 and $10.1 \mathrm{mV}$, respectively. $D$, Reversal potentials of the novel current measured at different extracellular $\mathrm{K}^{+}$concentrations closely matched the $\mathrm{K}^{+}$equilibrium potential given by the Nernst equation (straight line). Reversal potential was determined from leak-corrected instantaneous currents after steps to potentials between -144 and $-54 \mathrm{mV}$. Leakage conductance $(1.2 \pm 0.3,1.0 \pm 0.2$, and $1.3 \pm 0.5 \mathrm{nS}$ for $2,5.8$, and $12 \mathrm{~mm} \mathrm{~K}^{+}{ }_{\text {ex }}$, respectively) was determined by a linear fit to currents remaining after complete deactivation of the KCNQ-type current at potentials between - 144 and $-124 \mathrm{mV}$. Extracellular TEA (5 mm) was used to block $I_{\mathrm{K}, \mathrm{f}}$. Data for 2, 5.8, and $12 \mathrm{~mm} \mathrm{~K}^{+}$ex are mean \pm SD from 4,9 , and $5 \mathrm{IHCS}$, respectively.

OHCs was corroborated by single-cell RT-PCR. As illustrated in Figure $4 D$, transcripts of the KCNQ4 subunit were detected in $\mathrm{OHCs}$ (seven of eight cells tested) and in IHCs (four of seven cells tested), whereas PCR failed to amplify a KCNQ4 transcript in the five Deiters' cells tested, all of which showed positive signals for GAPDH.

This result is nicely complemented by recent work describing expression of KCNQ4 in both types of cochlear hair cells on the basis of whole-mount in situ hybridization and RT-PCR analysis (Beisel et al., 2000). Base-to-apex gradients as seen in these in situ hybridizations were not investigated here because of the weak immunofluorescence signal in IHCs. Together, electrophysiological recordings, immunocytochemistry, and single-cell PCR analysis strongly suggest that IHCs are endowed with KCNQ4 channels, giving rise to a current that is virtually indistinguishable from $I_{\mathrm{K}, \mathrm{n}}$, the major $\mathrm{K}^{+}$conductance in OHCs. Because of its activation at very negative voltages, the KCNQ current of IHCs

A

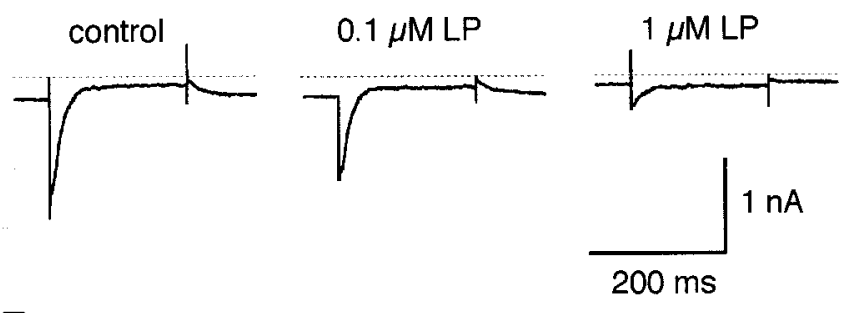

B

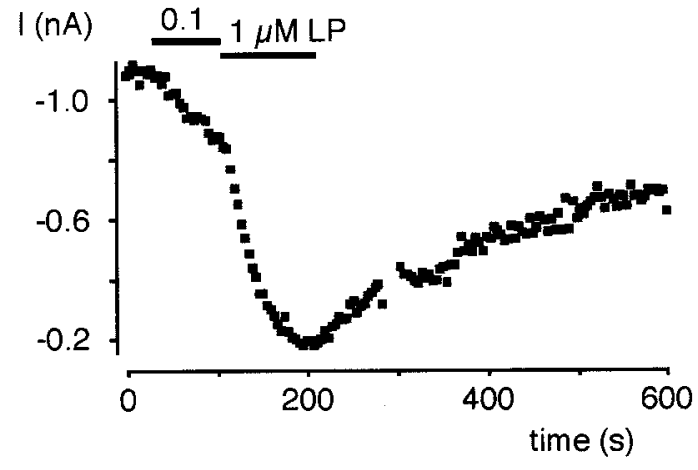

rel. current

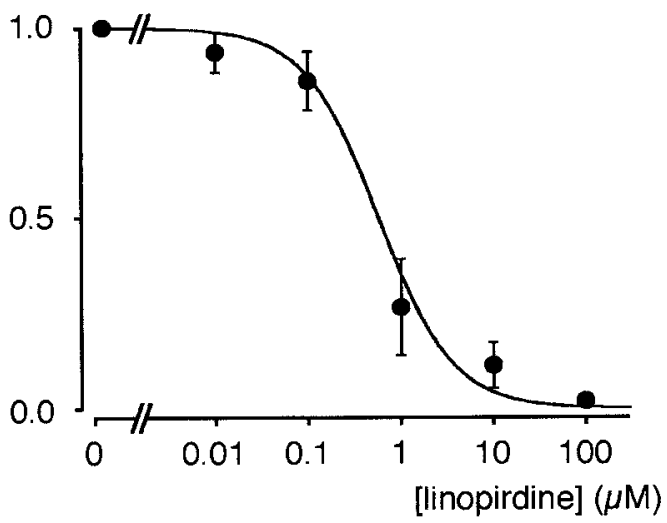

Figure 3. The $\mathrm{IHC}$ resting $\mathrm{K}^{+}$current is sensitive to the KCNQ-channel blocker linopirdine. A, KCNQ current recorded in IHCs in response to voltage steps from -64 to $-144 \mathrm{mV}$ before and after application of linopirdine at the concentrations indicated. Extracellular [K $\left.{ }^{+}\right]$was $20 \mathrm{~mm}$ throughout these experiments to increase the KCNQ current amplitude; dotted lines indicate zero-current level. $B$, Time course of linopirdine block shown for the cell in $A$. Symbols indicate amplitude of the transient inward current in response to each of the repetitive hyperpolarizing pulses. C, Linopirdine dose-inhibition curve of the KCNQ current measured as in A and B. Continuous line is a fit of the Hill equation to the data (see Results). Each data point represents mean \pm SD of four to eight IHCS.

provides the main source of the resting potential of the cell. It should be added at this point that the KCNQ current, as described above, was also observed in IHCs from rat. There, channel activation was characterized by $V_{\mathrm{h}}=-82.6 \pm 4.4 \mathrm{mV}$ and $\alpha=10.3 \pm 0.8 \mathrm{mV}(n=6)$; current amplitude, $I_{\max }-120 \mathrm{mV}$, was $-0.37 \pm 0.15 \mathrm{nA}$, and the corresponding slope conductance at $V_{\mathrm{R}}$ provided by the KCNQ channels was $9.3 \pm 3.8 \mathrm{nS}$.

KCNQ channels control the resting submembrane $\left[\mathrm{Ca}^{2+}\right]$ in cochlear IHCs

Current-clamp experiments as in Figure 1 clearly demonstrated that BK channels did not contribute appreciably to the $\mathrm{K}^{+}$conductance of the cell at the normal $V_{\mathrm{R}}$; a substantial portion of 

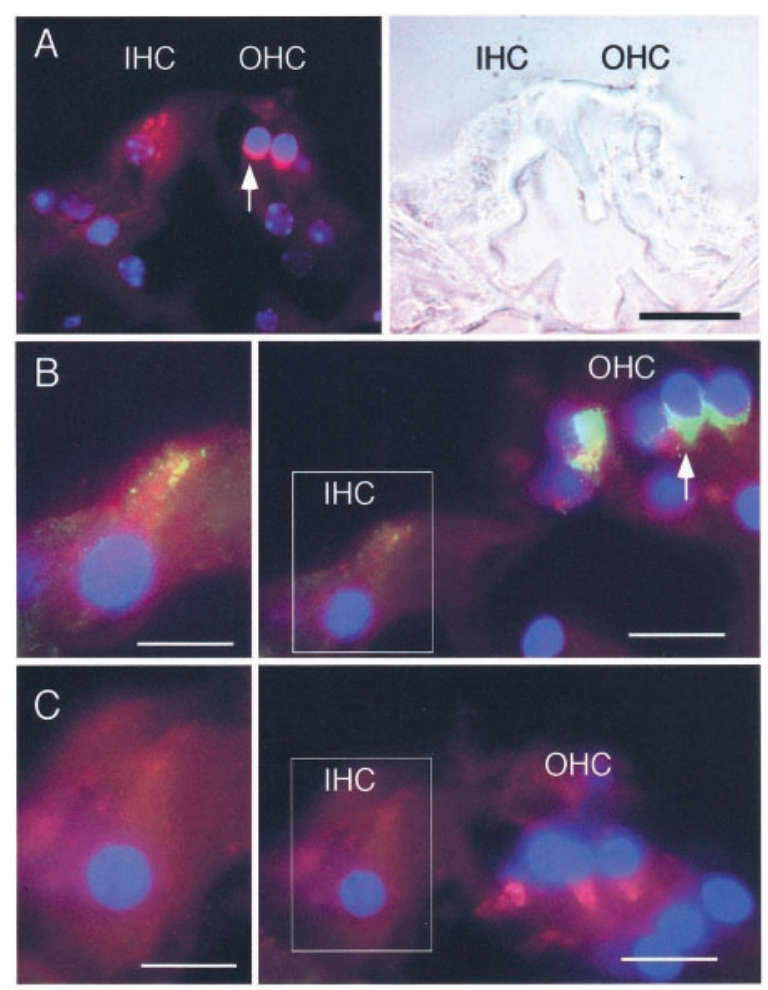

D
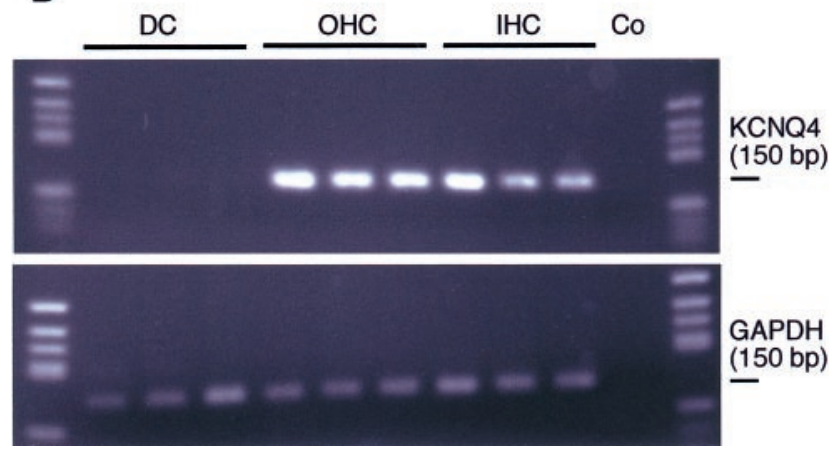

Figure 4. KCNQ4 immunoreactivity and single-cell PCR analysis of cochlear IHCS. A, Left, Confocal immunofluorescence image of the organ of Corti (midbasal turn, 6-week-old mouse) stained with the rabbit anti-KCNQ4 antibody (red) and DAPI (nuclear staining, blue). Right, Differential interference contrast image of the cryosection shown in A. Scale bar, $20 \mu \mathrm{m} . B, C$, Right, Cryosections as in $A$ stained with the goat anti-KCNQ4 antibody ( green) in the absence $(B)$ or presence $(C)$ of the antigenic peptide (see Materials and Methods) imaged by conventional immunofluorescence microscopy (midbasal turn, 4-week-old mouse); other fluorescence signals are from the anti-synaptophysin antibody (red) and DAPI. Scale bar, $20 \mu \mathrm{m}$. Left, Enlarged view of the IHCs shown at right. Scale bar, $10 \mu \mathrm{m}$. Note that KCNQ4 immunoreactivity is found in both $\mathrm{OHCs}$ and IHCs with an intense staining at the basal pole of $\mathrm{OHCs}$ (indicated by arrows) and a weaker and nonuniform signal in IHCS. D, Agarose gel analysis of the multiplex single-cell RT-PCR performed in the cell types indicated (DC, Deiters' cell); GAPDH was used as a control for successful isolation of mRNA. Co indicates the control PCR performed with extracellular fluid collected directly adjacent to IHCS.

these channels, however, was activated when $V_{\mathrm{R}}$ was shifted to depolarized potentials as a result of block of the KCNQ4 channels. Activation of BK channels at potentials as negative as -65 $\mathrm{mV}$ is thought to require $\left[\mathrm{Ca}^{2+}\right]_{\mathrm{i}}$ in the upper micromolar range (Adelman et al., 1992; Cui et al., 1997), suggesting that the linopirdine-induced depolarization led to a voltage-dependent increase in $\left[\mathrm{Ca}^{2+}\right]_{\mathrm{i}}$, most likely arising from the activation of voltage-gated $\mathrm{Ca}^{2+}$ channels $\left(\mathrm{Ca}_{\mathrm{V}}\right)$. Consistent with this idea, a
A
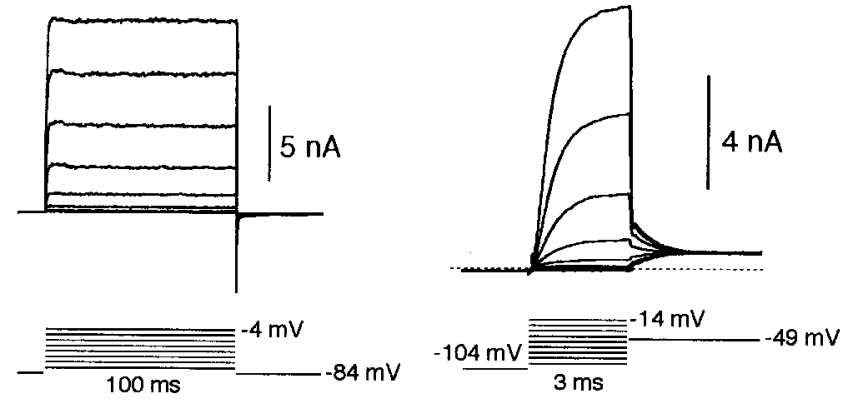

C

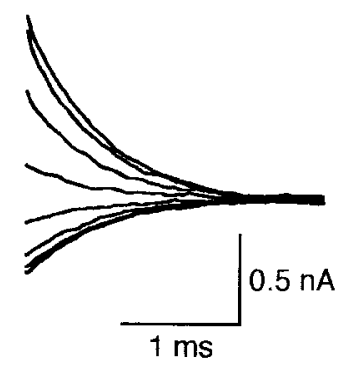

$\mathrm{D}$

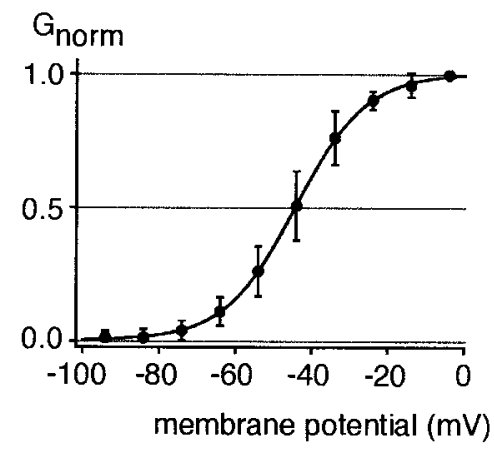

Figure 5. Voltage dependence of BK currents in IHCS. A, BK currents $\left(I_{\mathrm{K}, \mathrm{f}}\right)$ recorded in isolation using $10 \mathrm{~mm}$ 4-AP in the pipette and $1 \mu \mathrm{m}$ linopirdine in the extracellular medium in response to the voltage protocol indicated (residual $R_{\mathrm{s}}, 0.35 \mathrm{M} \Omega$ ). $B$, Voltage dependence of BK currents measured with the tail current protocol indicated. Voltage steps to the various potentials were kept as short as possible ( $3 \mathrm{msec}$ ) to avoid artifacts caused by $\mathrm{K}^{+}$accumulation near the membrane resulting from the large outward currents (residual $R_{\mathrm{s}}, 0.3 \mathrm{M} \Omega$ ). $C$, Tail currents from the experiment in C shown at enlarged scales. $D, G-V$ relationship obtained from experiments as in $B$ with residual $R_{\mathrm{s}} \leq 0.35 \mathrm{M} \Omega$. Tail current amplitudes were taken $0.2 \mathrm{msec}$ after the step to $-49 \mathrm{mV}$ and normalized to current amplitude at saturation $\left(I_{\max }\right)$ obtained from a Boltzmann fit to the current-voltage relationship for each cell. Continuous line shows a Boltzmann fit to the averaged data (mean \pm SD of 6 experiments), yielding values for $V_{\mathrm{h}}$ and $\alpha$ of -44.6 and $8.9 \mathrm{mV}$, respectively.

hallmark of IHC $\mathrm{Ca}^{2+}$ channels ( $\alpha 1 \mathrm{D}$ L-type $\mathrm{Ca}^{2+}$ channels, $\mathrm{Ca}_{\mathrm{V}} 1.3$ ) is their unusually negative activation range (Platzer et al., 2000; Xu and Lipscombe, 2001).

To test this idea, $\left[\mathrm{Ca}^{2+}\right]_{\mathrm{i}}$ was assessed by using the BK channels of IHCs as a $\mathrm{Ca}^{2+}$ sensor. First, we measured steady-state activation of BK channels as a function of membrane potential in the whole-cell mode (Fig. $5 A, B$ ). Isolation of BK currents was achieved by blocking all other $\mathrm{K}^{+}$conductances of IHCs with linopirdine (extracellular side, $1 \mu \mathrm{M}$ ) and 4-AP (intracellular side, $10 \mathrm{mM}$ ). $G-V$ curves were determined from tail currents following voltage steps to different potentials (Fig. $5 B, C$ ) and analyzed by fitting with a Boltzmann function (Fig. $5 D$ ). $V_{\mathrm{h}}$ and slope factor obtained by this procedure were $-44.7 \pm 4.3$ and $8.3 \pm 1.0 \mathrm{mV}$, respectively ( $n=6$ IHCs). Next, we determined the sensitivity of the IHC BK channels to intracellular $\mathrm{Ca}^{2+}$. Intracellular solutions with different free $\left[\mathrm{Ca}^{2+}\right]_{\mathrm{i}}$ were applied to the cytoplasmic face of inside-out patches excised from IHCs. The BK currents measured in these patches, typically $\sim 0.5 \mathrm{nA}$ in amplitude (Fig. 6A), were probed for their voltage dependence of activation at each $\left[\mathrm{Ca}^{2+}\right]_{\mathrm{i}}$ by tail current analysis. As shown in Figure $6, A$ and $B$, the voltage required for half-maximal activation of the channels was shifted to the left when $\left[\mathrm{Ca}^{2+}\right]_{\mathrm{i}}$ was increased from 0 to $10 \mu \mathrm{M}$. The $V_{\mathrm{h}}$ values obtained from Boltzmann fits to the $G-V$ 
A

$$
0 \mu \mathrm{M} \mathrm{Ca}^{2+}
$$
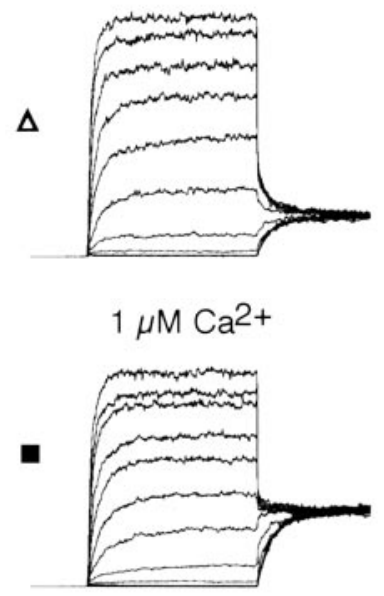

$3 \mu \mathrm{M} \mathrm{Ca}^{2+}$
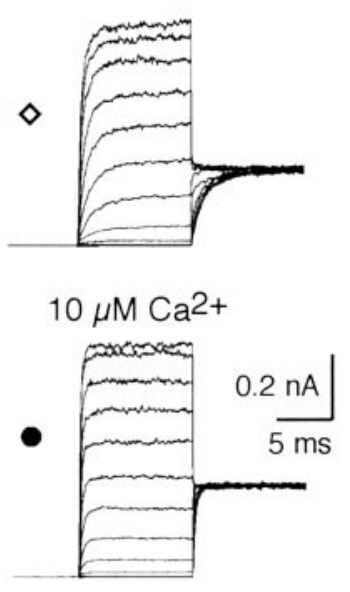

$10 \mu \mathrm{M} \mathrm{Ca}^{2+}$

B

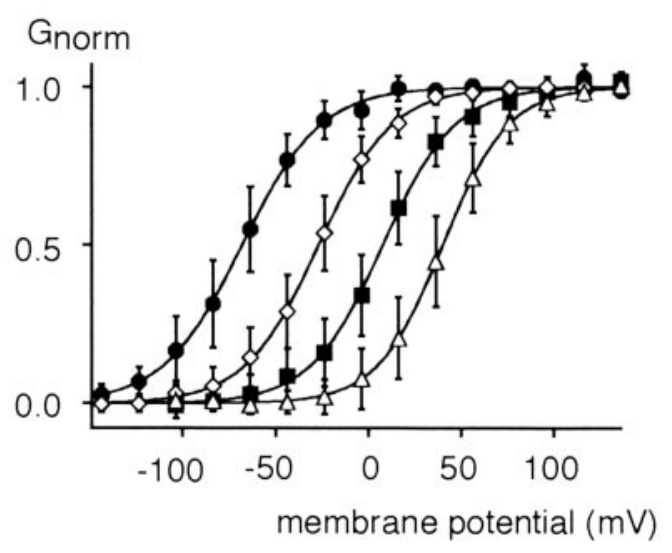

C

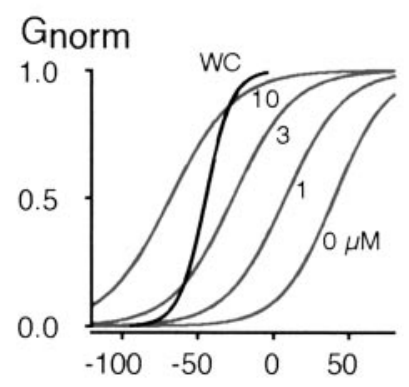

D

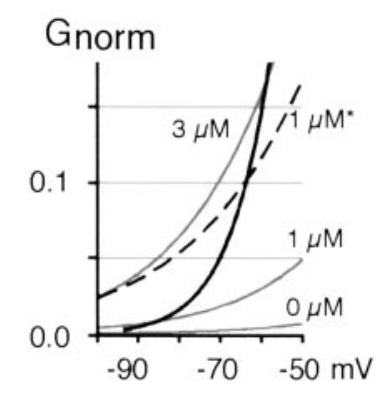

membrane potential $(\mathrm{mV})$

Figure 6. $\mathrm{Ca}^{2+}$ dependence of $\mathrm{BK}$ currents in inside-out patches reveals a voltagedependent increase of $\left[\mathrm{Ca}^{2+}\right]_{i}$ in the intact IHC. A, BK currents measured in response to depolarizing voltage steps in an inside-out patch excised from an $\mathrm{IHC}$ at the $\left[\mathrm{Ca}^{2+}\right]_{\mathrm{i}}$ indicated. Voltage protocols were as follows: left $\left(0\right.$ and $\left.1 \mu \mathrm{M} \mathrm{Ca}{ }^{2+}\right)$, holding potential $\left(V_{H}\right),-104 \mathrm{mV}$; voltage steps, -104 to +136 in $20 \mathrm{mV}$ increments; tail current voltage $\left(V_{T}\right),+26 \mathrm{mV}$; right (3 and $10 \mu \mathrm{M}\left(\mathrm{Ca}^{2+}\right), V_{\mathrm{H}},-104 \mathrm{mV}$; voltage steps, -144 to $+116 \mathrm{mV}$ in $20 \mathrm{mV}$ increments; $V_{T}$, $+11 \mathrm{mV}$. Each trace is averaged from 20 individual current recordings; $10 \mathrm{~mm}$ 4-AP was present in all solutions to block other $\mathrm{K}^{+}$currents. $B, G-V$ relationships of IHC BK channels at $0,1,3$, and $10 \mu \mathrm{M} \mathrm{Ca}{ }^{2+}$ obtained from 21, 15, 11 , and 12 patches using tail current analysis as described in Figure 5D. Symbols refer to the different $\left[\mathrm{Ca}^{2+}\right]_{\mathrm{i}}$ indicated in $A$. C, Overlay of BKactivation curves as obtained from patch and whole-cell measurements. Curves shown are fits to the data replotted from Figure $5 D$ [whole-cell (WC), black line] and from $B$ (inside-out patch, gray lines). Note that activation of BK currents in the intact cell displays a substantially steeper voltage depen- curves were $39.0 \pm 11.0,6.8 \pm 10.7,-27.6 \pm 10.2$, and $-68.9 \pm 10.8$ $\mathrm{mV}$ for $\left[\mathrm{Ca}^{2+}\right]_{\mathrm{i}}$ of $0,1,3$, and $10 \mu \mathrm{M}$, respectively $(n=21,15,11$, and 12 patches); the slope factor was $\sim 18 \mathrm{mV}$, independent of $\left[\mathrm{Ca}^{2+}\right]_{\mathrm{i}}$ (Fig. 6A,B). Similar to previous reports (Cui et al., 1997), the increase in $\left[\mathrm{Ca}^{2+}\right]_{\mathrm{i}}$ resulted in a decreased time constant for channel activation (Fig. $6 A$ ). In addition to the variance of the $V_{\mathrm{h}}$ values at a given $\left[\mathrm{Ca}^{2+}\right]_{\mathrm{i}}$, we occasionally observed a drift in $V_{\mathrm{h}}$ over several minutes toward positive potentials. Such data were excluded from further analysis. However, this observation suggests that voltage and/or $\mathrm{Ca}^{2+}$ dependence of BK channels may be modulated in IHCs. Moreover, the direction of this shift suggests that the most negative $G-V$ curves recorded in patches may best represent the properties of the BK channels in the whole-cell situation.

Comparison of the $G-V$ curves recorded in whole-cell mode with those determined in excised patches with defined $\left[\mathrm{Ca}^{2+}\right]_{i}$ now allowed for an estimation of the actual $\left[\mathrm{Ca}^{2+}\right]_{\mathrm{i}}$ in the intact IHC (Fig. 6C,D). Thus, fractional activation of BK currents in whole IHCs at potentials more negative than $-70 \mathrm{mV}$ was smaller than or comparable with that obtained with $1 \mu \mathrm{M}\left[\mathrm{Ca}^{2+}\right]_{\mathrm{i}}$ (Fig. 6C,D), suggesting low values for $\left[\mathrm{Ca}^{2+}\right]_{\mathrm{i}}$ around the typical $V_{\mathrm{R}}$ of IHCs of approximately $-72 \mathrm{mV}$. At more depolarized potentials of approximately $-65 \mathrm{mV}$, however, activation of whole-cell BK currents approached the mean activation curve at $\left[\mathrm{Ca}^{2+}\right]_{\mathrm{i}}=3 \mu \mathrm{M}$ in excised patches. If the most negative $G-V$ curve recorded in a patch with $1 \mu \mathrm{M}\left[\mathrm{Ca}^{2+}\right]_{\mathrm{i}}$ (Fig. 6 A, asterisk) is used as the reference, a lower limit for $\left[\mathrm{Ca}^{2+}\right]_{\mathrm{i}}$ of $1 \mu \mathrm{M}$ is obtained at $-65 \mathrm{mV}$. This indicated that depolarizations as induced by block of the KCNQ4 channels were accompanied by a rise in submembrane $\left[\mathrm{Ca}^{2+}\right]_{\mathrm{i}}$ to $1-3 \mu \mathrm{M}$ (Fig. $6 \mathrm{D}$ ). This estimation assumes a homogeneous submembrane $\left[\mathrm{Ca}^{2+}\right]_{\mathrm{i}}$. Alternatively, the rise in submembrane $\left[\mathrm{Ca}^{2+}\right]_{\mathrm{i}}$ may be more localized; in this case, the fraction of $\mathrm{BK}$ channels activated may even experience a higher $\left[\mathrm{Ca}^{2+}\right]_{\mathrm{i}}$. Overall, the activation curve of BK channels recorded in whole-cell configuration was considerably steeper than any of the $G-V$ values determined in inside-out patches at defined $\left[\mathrm{Ca}^{2+}\right]_{\mathrm{i}}$. This difference indicated a progressive increase in $\left[\mathrm{Ca}^{2+}\right]_{\mathrm{i}}$ with depolarization of the IHC between -80 and $0 \mathrm{mV}$ and most likely resulted from the activation of $\mathrm{Ca}^{2+}$ currents, which themselves were obscured by the large $\mathrm{K}^{+}$currents in the recordings shown.

Together, these results strongly suggested that the $\mathrm{K}^{+}$conductance mediated by KCNQ4 channels not only sets $V_{\mathrm{R}}$ of the IHCs in the isolated cochlea but thereby also curtails the submembrane $\mathrm{Ca}^{2+}$ level to low concentrations.

\section{Discussion \\ KCNQ4 currents in IHCs}

Detailed investigation of the $\mathrm{K}^{+}$conductances in cochlear IHCs showed that these sensory cells are endowed with a voltagedependent $\mathrm{K}^{+}$current distinct from the outwardly rectifying current components $I_{\mathrm{K}, \mathrm{f}}$ and $I_{\mathrm{K}, \mathrm{s}}$ (Kros and Crawford, 1990; Kros et al., 1998). Whereas the latter provide a large $\mathrm{K}^{+}$conductance

$\leftarrow$

dence than when recorded with constant $\left[\mathrm{Ca}^{2+}\right]_{\mathrm{j}}$. D, BK activation near the resting potential of the IHC shown at enlarged scale. (urve labeled with an asterisk is the fit to the individual $G-V$ relationship at $1 \mu \mathrm{m} \mathrm{Ca}{ }^{2+}$ that yielded the most negative $V_{\mathrm{h}}(-11 \mathrm{mV})$. Intersection of wholecell activation curve with mean activation at $3 \mu \mathrm{m}$ occurs at approximately $-59 \mathrm{mV}$, and with the leftmost activation curve at $1 \mu \mathrm{M} \mathrm{Ca}{ }^{2+}$ occurs at approximately $-64 \mathrm{mV}$, indicating a whole-cell $\left[\mathrm{Ca}^{2+}\right]_{\mathrm{i}}$ of $1-3 \mu \mathrm{m}$ at $-65 \mathrm{mV}$. 
activated on depolarization, the novel current contributes a smaller overall conductance. However, its negative range of activation renders it the predominant $\mathrm{K}^{+}$conductance at the resting potential of the cell measured in the isolated organ of Corti.

Identification of this current as being carried by KCNQ4 channels is based on several findings. First, it shares all characteristics with $I_{\mathrm{K}, \mathrm{n}}$, the major $\mathrm{OHC} \mathrm{K}^{+}$current that is generally thought to be carried by KCNQ4 channels (Marcotti and Kros, 1999; Jentsch, 2000; Kharkovets et al., 2000). This similarity includes the very negative range of activation $\left(V_{\mathrm{h}}\right.$ of $-84 \mathrm{mV}$ in OHCs) (Marcotti and Kros, 1999), a high sensitivity to linopirdine ( $\mathrm{IC}_{50}$ of $0.7 \mu \mathrm{M}$ for OHCs) (Marcotti and Kros, 1999), and the kinetic properties (data not shown) (Housley and Ashmore, 1992). Second, its pharmacological profile is characterized by a high sensitivity to the KCNQ-channel blockers linopirdine and XE991 together with insensitivity to TEA and 4-AP (Wang et al., 1998; Kubisch et al., 1999; Hadley et al., 2000). Third, expression of KCNQ4 in IHCs was confirmed by immunocytochemistry and single-cell RT-PCR.

Expression of KCNQ4 has so far been thought to be restricted to cochlear OHCs, vestibular hair cells, and central auditory neurons (Kubisch et al., 1999; Kharkovets et al., 2000). However, expression in IHCs might have been missed because of the lower expression level and a less dense localization within the plasma membrane. Indeed, recent reports point toward expression of KCNQ4 in mouse and guinea pig IHCs on the basis of immunofluorescence (Kharkovets et al., 2000) and in mouse IHCs on the basis of in situ hybridization and RT-PCR analysis (Beisel et al., 2000). Other members of the KCNQ family have not been detected unequivocally in the organ of Corti, but a weak RT-PCR signal for KCNQ3 has been reported for cochlear tissue (Kubisch et al., 1999). Thus, the possibility of heteromeric KCNQ4/3 channels in hair cells cannot be ruled out completely at present.

It seems worth mentioning that the gating properties of KCNQ4 channels in both types of cochlear hair cells are significantly different from any homomerically or heteromerically assembled KCNQ channel characterized in heterologous expression systems. These differences include activation of channels at very negative potentials, which was never observed for cloned KCNQ channels, and the activation kinetics, which are much slower in recombinant channels (Wang et al., 1998; Kubisch et al., 1999; Schroeder et al., 2000; Sogaard et al., 2001). The molecular determinants of these differences in channel gating are currently unknown.

\section{Properties of BK channels in IHCs}

The response properties of IHCs to the depolarizing receptor current are determined primarily by a fast outwardly rectifying $\mathrm{K}^{+}$conductance called $I_{\mathrm{K}, \mathrm{f} \cdot}$ This current is carried by the largeconductance $\mathrm{Ca}^{2+}$ - and voltage-activated BK channels, as indicated by its sensitivity to the BK blockers iberiotoxin and charybdotoxin and its submillisecond activation and deactivation kinetics (Kros and Crawford, 1990; Kros et al., 1998). In this study, we used BK channels as sensors to estimate $\left[\mathrm{Ca}^{2+}\right]_{\mathrm{i}}$ in IHCs. BK channels are gated by both transmembrane voltage and $\left[\mathrm{Ca}^{2+}\right]_{\mathrm{i}}$, such that the voltage range of activation shifts toward hyperpolarized potentials with increasing $\left[\mathrm{Ca}^{2+}\right]_{\mathrm{i}}$ (Cui et al., 1997). Although all BK channels are transcribed from a single gene locus, Slo, their $\mathrm{Ca}^{2+}$ sensitivity differs between cell types because of extensive alternative splicing (Tseng-Crank et al., 1994), association with $\beta$-subunits (McManus et al., 1995;
Brenner et al., 2000), and protein phosphorylation (Levitan, 1994; Hall and Armstrong, 2000). We therefore determined activation parameters in inside-out patches from IHCs using different $\left[\mathrm{Ca}^{2+}\right]_{\mathrm{i}}$. Surprisingly, the BK channels of IHCs showed particularly negative activation ranges. Thus, the voltage required for half-maximal activation at $\left[\mathrm{Ca}^{2+}\right]_{\mathrm{i}}$ of $1 \mu \mathrm{M}$ was $+7 \mathrm{mV}$, whereas it can be as positive as +50 to $100 \mathrm{mV}$ in other cell types and expression systems (Cui et al., 1997; Hurley et al., 1999). Accordingly, low micromolar concentrations of $\mathrm{Ca}^{2+}$ are sufficient to allow for substantial BK channel activation in IHCs on the working voltage range of these nonspiking cells. A similar negative activation range has been found in certain $\mathrm{BK}$ splice variants (Ransom et al., 2002) and in BK channels from lower vertebrate hair cells complexed with $\beta$-subunits (Jones et al., 1999).

In good agreement with previous data from guinea pig (Kros and Crawford, 1990), onset of BK channel activation in intact IHCs was approximately at $-70 \mathrm{mV}$ and showed a steeper voltage dependence than observed with constant $\left[\mathrm{Ca}^{2+}\right]_{\mathrm{i}}$ at excised patches. This indicated a progressive increase in $\left[\mathrm{Ca}^{2+}\right]_{i}$ with depolarization that is likely to result from activation of the IHC $\mathrm{Ca}_{\mathrm{V}}$ channels. In perfect agreement with the very negative activation of BK channels, the $\mathrm{Ca}_{\mathrm{V}}$ channels of IHCs are formed by $\alpha 1 \mathrm{D}$ $\left(\mathrm{Ca}_{\mathrm{V}} 1.3\right)$, which characteristically opens at potentials as low as $-65 \mathrm{mV}$ (Platzer et al., 2000; Xu and Lipscombe, 2001). Apparently, the small fraction of $\mathrm{Ca}_{\mathrm{V}}$ channels open at this potential is sufficient to increase $\left[\mathrm{Ca}^{2+}\right]_{\mathrm{i}}$ to $\sim 2 \mu \mathrm{M}$, at least in the close proximity of the BK channels (Fig. 6C,D).

\section{Function of KCNQ4 in IHCs}

Because of their negative activation range, the KCNQ4 channels are open over the complete voltage range adopted by the IHC, providing it with a "background" $\mathrm{K}^{+}$current. As shown by blocking this current, it can set the resting potential and consequently maintain low intracellular $\mathrm{Ca}^{2+}$ levels by favoring the closed state of $\mathrm{Ca}^{2+}$ channels. Furthermore, this current will contribute to the resting conductance of the IHC and thereby to its membrane time constant.

These conclusions, however, rely on the assumption that the resting potential in vivo is close to the values found in this patchclamp study $(-72 \mathrm{mV})$. This is because a shift in $V_{\mathrm{R}}$ of just +10 $\mathrm{mV}$ is sufficient to activate an appreciable conductance supplied by $I_{\mathrm{K}, \mathrm{f}}$ (Fig. $5 D$ ) and $I_{\mathrm{K}, \mathrm{s}}$ such that the impact of KCNQ channels on overall $\mathrm{K}^{+}$conductance and membrane potential will decrease. It should be noted that potential recordings with intracellular electrodes yielded more depolarized resting potentials of approximately $-40 \mathrm{mV}$ (Dallos, 1985). However, it has been argued convincingly that such depolarized potentials probably result from damage inherent to the impalement of microelectrodes into the IHC and that patch-clamp measurements will provide more realistic estimates of $V_{\mathrm{R}}$ (Kros, 1996).

\section{IHCs and DFNA2}

Mutations in the KCNQ4 gene are known to cause inherited autosomal dominant hearing loss in humans classified as DFNA2 (Kubisch et al., 1999). DFNA2 is characterized by a slowly progressing hearing loss that develops from high to low frequencies and finally leads to severe deafness (Marres et al., 1997; De Leenheer et al., 2002). On the basis of the strong expression of KCNQ4 in the basolateral membrane of OHCs, it was hypothesized that hearing loss in DFNA2 may be caused by a defect in $\mathrm{OHC} \mathrm{K}^{+}$ 
homeostasis. Loss of basolateral KCNQ4 channels could result in a cytoplasmic accumulation of $\mathrm{K}^{+}$that would finally lead to OHC degeneration (Kubisch et al., 1999; Jentsch, 2000). Although this mechanism would be compatible with the progressive nature of DFNA2, complete loss of OHCs will ultimately reduce hearing threshold by 40-50 dB (Ryan and Dallos, 1975). Profound hearing loss as reported for patients with DFNA2 is insufficiently explained by nonfunctional OHCs. Thus, additional pathophysiological mechanisms must apply. A contribution of central auditory pathways, in which neuronal KCNQ4 expression is found, has been proposed (Jentsch, 2000; Kharkovets et al., 2000). Alternatively, a more generalized degeneration of the organ of Corti, including OHCs and IHCs, may lead to severe hearing loss, as recently observed in a mouse model bearing a targeted gene deletion of the OHC-specific protein prestin (Liberman et al., 2002).

Our findings suggest involvement of IHCs in the development of the DNFA2 phenotype. In the first place, lack of KCNQ4 channels may lead to a destabilization of the membrane potential as shown above. Depolarization will in turn increase presynaptic activity of the IHC, and, consequently, resting firing rates of the auditory nerve fibers will rise. Interestingly, in some affected families, DFNA2 is associated with tinnitus, which might result from excessive afferent activity (Coucke et al., 1994; Kubisch et al., 1999). More importantly, our in vitro experiments suggest that even the moderate depolarization that results from loss of KCNQ channels will lead to an increase in intracellular $\mathrm{Ca}^{2+}$ levels, at least in a submembranous compartment. Although our results cannot show directly that permanent loss of KCNQ function will result in a sustained $\mathrm{Ca}^{2+}$ load of IHCs in vivo, a chronic $\mathrm{Ca}^{2+}$ overload may be a candidate for induction of degeneration of IHCs, which in turn would lead to complete hearing loss in the cochlear region (frequency range) affected.

Recent in situ hybridization data have shown a cochlear baseto-apex gradient of KCNQ4 expression in IHCs. The highest expression levels were found in basal, high-frequency IHCs (Beisel et al., 2000). Thus, the proposed hypothesis involving degeneration of IHCs could account for both progressive hearing loss resulting in complete deafness and the frequency dependence of hearing loss that develops from high toward lower frequencies in DFNA2 patients (De Leenheer et al., 2002).

\section{References}

Adelman JP, Shen KZ, Kavanaugh MP, Warren RA, Wu YN, Lagrutta A, Bond CT, North RA (1992) Calcium-activated potassium channels expressed from cloned complementary DNAs. Neuron 9:209-216.

Beisel KW, Nelson NC, Delimont DC, Fritzsch B (2000) Longitudinal gradients of KCNQ4 expression in spiral ganglion and cochlear hair cells correlate with progressive hearing loss in DFNA2. Brain Res Mol Brain Res 82:137-149.

Brenner R, Jegla TJ, Wickenden A, Liu Y, Aldrich RW (2000) Cloning and functional characterization of novel large conductance calcium-activated potassium channel beta subunits, hKCNMB3 and hKCNMB4. J Biol Chem 275:6453-6461.

Coucke P, Van Camp G, Djoyodiharjo B, Smith SD, Frants RR, Padberg GW, Darby JK, Huizing EH, Cremers CW, Kimberling WJ, Oostra BA, Vandeheyning PH, Willems PJ (1994) Linkage of autosomal dominant hearing loss to the short arm of chromosome 1 in two families. N Engl J Med 331:425-431.

Cui J, Cox DH, Aldrich RW (1997) Intrinsic voltage dependence and $\mathrm{Ca}^{2+}$ regulation of mslo large conductance Ca-activated $\mathrm{K}^{+}$channels. J Gen Physiol 109:647-673.
Dallos P (1985) Response characteristics of mammalian cochlear hair cells. J Neurosci 5:1591-1608.

Dallos P (1992) The active cochlea. J Neurosci 12:4575-4585.

De Leenheer EM, Huygen PL, Coucke PJ, Admiraal RJ, van Camp G, Cremers CW (2002) Longitudinal and cross-sectional phenotype analysis in a new, large Dutch DFNA2/KCNQ4 family. Ann Otol Rhinol Laryngol 111:267-274

Fuchs PA, Murrow BW (1992) Cholinergic inhibition of short (outer) hair cells of the chick's cochlea. J Neurosci 12:800-809.

Hadley JK, Noda M, Selyanko AA, Wood IC, Abogadie FC, Brown DA (2000) Differential tetraethylammonium sensitivity of KCNQ1-4 potassium channels. Br J Pharmacol 129:413-415.

Hall SK, Armstrong DL (2000) Conditional and unconditional inhibition of calcium-activated potassium channels by reversible protein phosphorylation. J Biol Chem 275:3749-3754.

Housley GD, Ashmore JF (1992) Ionic currents of outer hair cells isolated from the guinea pig cochlea. J Physiol (Lond) 448:73-98.

Hurley BR, Preiksaitis HG, Sims SM (1999) Characterization and regulation of $\mathrm{Ca}^{2+}$-dependent $\mathrm{K}^{+}$channels in human esophageal smooth muscle. Am J Physiol 276:G843-G852.

Jentsch TJ (2000) Neuronal KCNQ potassium channels: physiology and role in disease. Nat Rev Neurosci 1:21-30.

Jones EM, Gray-Keller M, Fettiplace R (1999) The role of $\mathrm{Ca}^{2+}$-activated $\mathrm{K}^{+}$channel spliced variants in the tonotopic organization of the turtle cochlea. J Physiol (Lond) 518:653-665.

Kharkovets T, Hardelin JP, Safieddine S, Schweizer M, El-Amraoui A, Petit C, Jentsch TJ (2000) KCNQ4, a K ${ }^{+}$channel mutated in a form of dominant deafness, is expressed in the inner ear and the central auditory pathway. Proc Natl Acad Sci USA 97:4333-4338.

Knipper M, Zinn C, Maier H, Praetorius M, Rohbock K, Kopschall I, Zimmermann U (2000) Thyroid hormone deficiency before the onset of hearing causes irreversible damage to peripheral and central auditory systems. J Neurophysiol 83:3101-3112.

Kros CJ (1996) Physiology of mammalian cochlear hair cells. In: The cochlea (Dallos P, Popper N, Fay R, eds), pp 318-385. New York: Springer.

Kros CJ, Crawford AC (1990) Potassium currents in inner hair cells isolated from the guinea-pig cochlea. J Physiol (Lond) 421:263-291.

Kros CJ, Ruppersberg JP, Rusch A (1998) Expression of a potassium current in inner hair cells during development of hearing in mice. Nature 394:281-284.

Kubisch C, Schroeder BC, Friedrich T, Lutjohann B, El-Amraoui A, Marlin S, Petit C, Jentsch TJ (1999) KCNQ4, a novel potassium channel expressed in sensory outer hair cells, is mutated in dominant deafness. Cell 96:437-446.

Levitan IB (1994) Modulation of ion channels by protein phosphorylation and dephosphorylation. Annu Rev Physiol 56:193-212.

Liberman MC, Gao J, He DZ, Wu X, Jia S, Zuo J (2002) Prestin is required for electromotility of the outer hair cell and for the cochlear amplifier. Nature 419:300-304.

Marcotti W, Kros CJ (1999) Developmental expression of the potassium current IK,n contributes to maturation of mouse outer hair cells. J Physiol (Lond) 520:653-660

Marres H, van Ewijk M, Huygen P, Kunst H, van Camp G, Coucke P, Willems P, Cremers C (1997) Inherited nonsyndromic hearing loss: an audiovestibular study in a large family with autosomal dominant progressive hearing loss related to DFNA2. Arch Otolaryngol Head Neck Surg 123:573-577.

McManus OB, Helms LM, Pallanck L, Ganetzky B, Swanson R, Leonard RJ (1995) Functional role of the beta subunit of high conductance calciumactivated potassium channels. Neuron 14:645-650.

Oliver D, Klocker N, Schuck J, Baukrowitz T, Ruppersberg JP, Fakler B (2000) Gating of $\mathrm{Ca}^{2+}$-activated $\mathrm{K}^{+}$channels controls fast inhibitory synaptic transmission at auditory outer hair cells. Neuron 26:595-601.

Platzer J, Engel J, Schrott-Fischer A, Stephan K, Bova S, Chen H, Zheng H, Striessnig J (2000) Congenital deafness and sinoatrial node dysfunction in mice lacking class D L-type $\mathrm{Ca}^{2+}$ channels. Cell 102:89-97.

Ransom CB, Liu X, Sontheimer H (2002) BK channels in human glioma cells have enhanced calcium sensitivity. Glia 38:281-291.

Ryan A, Dallos P (1975) Effect of absence of cochlear outer hair cells on behavioural auditory threshold. Nature 253:44-46. 
Santos-Sacchi J (1993) Voltage-dependent ionic conductances of type I spiral ganglion cells from the guinea pig inner ear. J Neurosci 13:3599-3611.

Schroeder BC, Hechenberger M, Weinreich F, Kubisch C, Jentsch TJ (2000) KCNQ5, a novel potassium channel broadly expressed in brain, mediates M-type currents. J Biol Chem 275:24089-24095.

Sogaard R, Ljungstrom T, Pedersen KA, Olesen SP, Jensen BS (2001) KCNQ4 channels expressed in mammalian cells: functional characteristics and pharmacology. Am J Physiol 280:C859-C866.

Takeno S, Harrison RV, Ibrahim D, Wake M, Mount RJ (1994) Cochlear function after selective inner hair cell degeneration induced by carboplatin. Hear Res 75:93-102.

Tseng-Crank J, Foster CD, Krause JD, Mertz R, Godinot N, DiChiara TJ, Reinhart PH (1994) Cloning, expression, and distribution of function- ally distinct $\mathrm{Ca}^{2+}$-activated $\mathrm{K}^{+}$channel isoforms from human brain. Neuron 13:1315-1330.

Wang HS, Pan Z, Shi W, Brown BS, Wymore RS, Cohen IS, Dixon JE, McKinnon D (1998) KCNQ2 and KCNQ3 potassium channel subunits: molecular correlates of the M-channel. Science 282:1890-1893.

Wang J, Powers NL, Hofstetter P, Trautwein P, Ding D, Salvi R (1997) Effects of selective inner hair cell loss on auditory nerve fiber threshold, tuning and spontaneous and driven discharge rate. Hear Res 107:67-82.

Wangemann P (2002) $\mathrm{K}^{+}$cycling and the endocochlear potential. Hear Res 165:1-9.

Xu W, Lipscombe D (2001) Neuronal $\mathrm{Ca}_{\mathrm{V}} 1.3_{\alpha} 1$ L-type channels activate at relatively hyperpolarized membrane potentials and are incompletely inhibited by dihydropyridines. J Neurosci 21:5944-5951. 